\section{SAMBAS E BAMBAS SEM O BREQUE DO ESTADO NOVO}

\section{Resenha de}

PARANHOS, Adalberto. Os desafinados: sambas e bambas no "Estado Novo". São Paulo: Intermeios/CNPq/Fapemig, 2015. 172p.

\section{Áureo}

\section{BUSETTO}

(D) aureohis@assis.unesp.br

Universidade Estadual Paulista Júlio de Mesquita Filho - UNESP Assis, São Paulo, Brasil

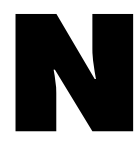

a década de 1980, o samba andava em baixa na indústria fonográfica, no rádio e na televisão. A mídia promovia larga e amplamente outros ritmos musicais. Muitos vaticinavam o fim do samba. Em reação a tal cantilena, Paulinho da Viola em Eu canto samba, integrado ao seu premiado disco homônimo lançado em 1989, canta que ele há muito tempo escutava "o papo furado dizendo que o samba acabou", ao que emenda resposta irônica: "só se for quando o dia clareou". Enfim, o sambista, com maestria e temperança, pontuava que não era porque o samba seguia preterido ou vitimado por alterações impostas pelos interesses comerciais da mídia que ele havia deixado de existir, alegar a vida e falar das coisas dos sambistas e admiradores do gênero, bem como de ser cantado e dançado nas rodas de samba em fundos de quintais.

Ainda naquela década, na historiografia era assinalado que sambistas durante o Estado Novo, então, empenhado em alçar o samba urbano carioca à tradução musical da nacionalidade, tinham submetido suas canções totalmente aos valores políticos e sociais calcados na ideologia trabalhista idealizada e difundida por aquele regime ditatorial, via o vigilante serviço do Departamento de Imprensa e Propaganda (DIP), criado no final de 1939 e atuante até o fim do regime, em 1945 (PEDRO, 1980; GOMES, 1982; VASCONCELLOS e SUZUKI JR., 1984).

Ainda que pretendesse revelar a censura sofrida e os esquemas de aliciamento do DIP investidos ao universo do samba, aquela historiografia caracteriza como dócil e passiva a adesão dos sambistas à ideologia estado-novista, mesmo essa se opondo 
radicalmente a elementos constituintes do samba urbano carioca, como, por exemplo, a malandragem e a boemia. Interpretação que, ademais, reforça a imagem de que o Estado Novo fora hegemônico, absoluto na vida cotidiana e mesmo na dimensão cultural, além de potencializar a mítica do líder máximo do trabalhismo, Getúlio Vargas.

Mas agora, com ampla e acurada pesquisa histórica, perpassada de igual sensibilidade e respeito com que Paulinho da Viola canta a gente e as coisas do mundo do samba, Adalberto Paranhos revela, em seu livro Os desafinados: sambas e bambas no "Estado Novo", que sambistas valeram-se em suas canções de "linhas de fuga" às investidas do DIP contra práticas e representações próprias do mundo do samba. Assim, o historiador assinala que bambas não foram somente sambistas que primavam pela qualidade do samba, mas, também, por saberem ou intuírem que nele apenas se podia admitir um tipo de breque, qual seja: aquela pausa do acompanhamento acentuadamente sincopado para intervenção declamatória do intérprete do samba. Enfim, se depreende da análise de Paranhos que, calcada em seu expressivo e firme conhecimento histórico e musical, as tentativas de doutrinação do trabalhismo varguista sobre o riscado do samba foram recebidas de maneira parecida à recepção dispensada a uma inautêntica baiana ao tentar entrar na roda de samba; valendo-se aqui de cena caracterizada pela letra do samba Falsa baiana, da autoria de Geraldo Pereira, lançado em 1944, na voz de Ciro Monteiro.

Na letra do seu samba, Geraldo Pereira narra que a impostura da falsa baiana se revela ao pessoal da roda de samba por ela não saber mexer, remexer e dar nó nas cadeiras. No seu livro, Paranhos evidencia que as intenções do Estado Novo em "higienizar à poética do samba", em conformidade com a ideologia trabalhista, fora sentida e percebida por bambas como embuste em relação às coisas que nutriam e, mesmo, alegravam a vida de sambistas e do mundo a sua volta. Afinal, aquela imposição oficial era obra da elite, coisa de gente que sequer tinha patente para tirar samba - condição cultuada e defendida no meio sambista - e que imaginava, de maneira prepotente, bambas apenas dançassem conforme a música tocada. Completo desconhecimento da criatividade escápole dos que nasciam e queriam morrer com o samba, os quais em seu cotidiano tiravam de letra adversidades sociais impingidas pelos agentes do mando por meio da vigilância e força policiais. Dribles dados tanto aos apertos da subsistência, à época, amplamente pautada pelo desemprego e subemprego, quanto à ordem imposta que invariavelmente serviam de motes às letras de seus sambas, caracterizando o elo entre experiências de vida e a composição de suas canções, as quais, costumeiramente, ganhavam a aderência do seu típico público.

$\mathrm{Na}$ tentativa da falsa baiana entrar no samba, prossegue a letra de Geraldo Pereira, ninguém bate palmas, grita oba ou abre a roda para ela. As investidas do DIP para "higienizar" o samba, revelam as páginas de Os desafinados..., receberam por parte de bambas parecida recepção. E se eles, vez ou outra, aplaudiram, lançaram vivas ou abriram espaço em seus sambas aos valores políticos e sociais impostos pelo Estado Novo, não o fizeram por aquiescência própria e, mais ainda, não os dotaram necessariamente de igual sentido ao 
desejado por aquele regime. Se houve, conclui Adalberto Paranhos, a existência de uma plêiade de compositores e composições populares que se prestaram a enaltecer e exaltar o ideário estado-novista, fosse por meio de aliciamento ou de censura do DIP, o coro de sambistas descontentes com valores estado-novistas não deixou de se fazer presente no cenário musical, ainda que de maneira sútil e segundo as circunstâncias.

Não há como deixar de registar que Adalberto Paranhos lega um livro que expressa o cume da pesquisa na área de História, uma vez que enfoca tema e vale-se de fontes já tratados pela historiografia anterior, porém, fornecendo original e acurada interpretação deles por meio de abordagem inovadora. Com sua pesquisa, o historiador trata de um velho tema da história política - o poder do Estado na sociedade - e uma temática enfocada pela historiografia nas últimas décadas - o Estado Novo e a construção da nacionalidade - por um ângulo muito pouco tratado na área de História - o samba. Assim, a pesquisa e o livro de Paranhos se desenrolam com base na compreensão do entrelaçamento das dimensões da cultura, política e do social vigentes no Estado Novo, sem, contudo, desafinar quer nas notas necessárias para compreender as especificidades históricas de cada uma daquelas dimensões, quer nas dispensadas ao tratamento histórico das interseções entre elas. E como resultado final oferece novos e acurados acordes ao conhecimento historiográfico sobre as relações entre política e samba durante a ditadura varguista, os quais não poderão ser prescindidos em futuros estudos históricos sobre a política, sociedade e cultura na ditadura do Estado Novo, assim como nos voltados para história do samba, sob o risco de o pesquisador que agir ao contrário desafinar em suas conclusões.

Tomando o samba, ao mesmo tempo, como objeto e fonte de sua pesquisa, Paranhos transcende a limitada e arriscada análise centrada na letra ou partitura do documento canção. Ao valer-se de registros fonográficos gravados à época estudada, o historiador, por entender que a canção não existe em abstrato e o (re)interpretar também é compor, empreende, com grande acuidade, uma análise sobre a realização sonora da canção, englobando desde a orquestração musical à interpretação vocal, posto defender que tais expedientes são portadores de significações. É nesse diapasão que o autor revela que o emprego do breque em vários sambas da época funcionara para o intérprete se distanciar, ironizar, debochar e, mesmo, negar o que foi cantado na parte anterior da letra.

E quando da análise das letras dos sambas, Paranhos destaca palavras e expressões muito próprias às representações de criadores e cultores do gênero no período enfocado, dotando-as de historicidade, como, por exemplo, o faz com as palavras 'batucada' e 'orgia'. Paranhos nos elucida que 'batuque' ou 'batucada' expressavam, ao mesmo tempo e paulatinamente a partir dos anos 1930, sinônimo ou referência de samba e elementos constituidores dele, sobremaneira quando se procurava dar ênfase na autenticidade do gênero e no seu valor como representante musical do povo brasileiro. Embora, saliente que ambos os termos pudessem ser empregados quando se intencionava detratar o samba, segundo apreciações de lugares e comportamentos ligados ao gênero, isto é, os da 
população negra, mestiça e marginalizada. Em relação à 'orgia', nos ensina que a palavra expressava, nos sambas dos anos de 1930, o sentido de festa ou diversão pândega, logo, não se prendendo à conotação sexual que o termo pode suscitar, contudo, expressando ação oposta ao penar do mundo do trabalho, ainda que, dependendo do samba, a labuta com o trabalho pudesse oscilar entre honradez e humilhação.

Ademais, o livro de Adalberto Paranhos serve como dínamo a novos estudos históricos. Qual popular samba enredo após desfilar pela avenida, o conhecimento trazido pelo livro tende a ficar batucando na cabeça de atentos leitores sobre possibilidades de pesquisas ocupadas com as relações samba/política em outros períodos, bem como as de outras manifestações da cultura popular com o Estado e políticas governamentais. Batucada possível de se apossar da mente do leitor já nas páginas da introdução - intitulada sabiamente como Palavra Prima - e nas integradas ao primeiro capítulo do livro.

Com a leitura de ambas as partes, os leitores podem vislumbrar o rigor das reflexões sobre o saber historiográfico e elementos teórico-conceituais que Paranhos investiu à elaboração de sua temática de estudo, assim como o seu empenho na consecução da sua ampla e acurada pesquisa documental. Somam-se a isto férteis reflexões do historiador acerca do estatuto das variadas fontes consultadas (discos, jornais, revistas e conteúdos de programas de rádio, depoimentos), além de detalhes sobre a busca por elas, tarefa que envolveu dificuldades tanto da ordem de localização quanto de acesso. Registro que, ao mesmo tempo, facilita e estimula novas pesquisas com a documentação levantada. Louvável generosidade do autor para com a comunidade de pesquisadores interessados em estudos históricos sobre o Estado Novo e o samba.

No primeiro capítulo do livro, Paranhos apresenta um balanço reflexivo sobre as perspectivas teóricas que alicerçaram anteriores interpretações historiográficas ocupadas com a análise do Estado Novo e a dimensão do poder desse regime. Nessa direção, conceitos como hegemonia, dominação, resistência, apropriação e ressignificação, bem como questões teóricas centrais ligadas a eles, são enfocados, discutidos e refletidos pelo autor para definir e substanciar, de maneira objetiva e firme, a sua adesão à perspectiva da 'história vista de baixo'. Capítulo que muito se distancia das partes introdutórias usualmente constantes em trabalhos acadêmicos e livros de difusão da pesquisa em História, posto que expressa diálogo ativo e reflexivo do pesquisador com referenciais teórico e historiográficos convergentes ou divergentes à perspectiva de análise e interpretação por ele compostas.

Longe de encerrar sua pesquisa sob a perspectiva de análise que tudo concede ao poder do Estado e centra-se na busca por marcar o império dos projetos de dominação estatal, Paranhos enceta uma abordagem que the possibilitou apreender os conflitos, as contradições, enfim, "o caráter dialético da dominação". Para tanto, parte de elementos teóricos engendrados por Pierre Bourdieu (2002) e Michel Foucault (1977; 1979)- votados à análise de práticas e dispositivos das disputas encontráveis nas relações de poder que atravessam os diferentes domínios sociais que compõem a sociedade - e de E.P. Thompson 
(1998) e Raymond Willians (1992) - ocupados em conhecer e analisar forças de lutas e resistências contra-hegemônicas.

Com tal foco analítico investido à plêiade de fontes pesquisadas, Paranhos evidencia, nos dois capítulos seguintes, como sambistas conseguiam, ao mesmo tempo, desempenhar, em meio à sua afirmação social, papel decisivo na incorporação do samba à galeria de símbolos nacionais e registrarem composições e interpretações dissonantes aos valores políticos e sociais ditados pelo Estado Novo, burlando as tentativas do DIP em "regenerar" o temário do gênero, extirpando desse representações sociais de mundo tidas como inconvenientes ao trabalhismo.

Dentro desse quadro, bambas investiram aos seus sambas, não sem sucesso, uma linguagem e/ou sonoridade prenhes de sentidos ambíguos, transpondo ao seu universo musical expediente tão comum no cotidiano da malandragem, geralmente empregado para despistar pequenos ilícitos e contravenções diante dos agentes da ordem. Nessa direção, bambas, como bem estabelece Paranhos, desenrolavam "linhas de fuga em relação à palavra estatal", incorporando seus sambas às disputas de representações sobre o trabalho e o trabalhador, as quais, consonantes às experiências dos sambistas, podem ser sintetizadas pela letra de um samba da época: "o trabalho não dá camisa ao trabalhador".

Mas Paranhos também capta a reação de bambas às investidas do Estado Novo em regular as relações de gênero, decorrência do entendimento dos ideólogos do regime que desajustes do mundo do trabalho contribuíam à manutenção de conflitos de gênero. Acentua que sambas com motes relativos às relações de gênero repercutiam as tratativas acerca do estabelecimento do Estatuto da Família entre o final dos anos de 1930 e o início da década seguinte. Apresenta como sambistas cantavam, de um lado, as insatisfações das mulheres no desempenho da função de provedoras do lar, em decorrência de seus maridos ou companheiros não assumirem ou negligenciarem aquele compromisso social - o que, aliás, como destacada o historiador, sambas que "não deixavam de retratar a sobrevivência de figuras masculinas que voltavam as costas ao trabalho"-, e, de outro, entoavam os lamentos de homens por conta de suas mulheres não se submeterem ao esperado papel social de dona de casa, preferindo elas a diversão. Assim, enfatiza o historiador, sambistas mesmo que admitissem a intromissão oficial na moral conjugal, mantiveram brechas em seus sambas para discordar e, mesmo, desprezar o ideário das relações de gênero difundido pelo regime estado-novista.

Há ainda que se considerar que os dois últimos capítulos iluminam ainda mais o que se conhece sobre a estrutura e dinâmica da indústria fonográfica e do rádio nos tempos do Estado Novo (CABRAL, 1990; LAGO, 1977), enfatizando ou revelando práticas e representações próprias de agentes integrados naquelas mídias, fossem em termos da programação musical de maneira geral, fossem em relação ao samba. Sem deixar de demarcar precisamente as interseções entre aquelas duas mídias eletrônicas e a imprensa no tratamento tanto das manifestações culturais populares/samba quanto das populações identificadas com elas. 
Sem dúvida, Os desafinados... se inscreve como livro original e inovador na historiografia sobre o Estado Novo e o samba, mas, também, como um ótimo guia a todos os interessados em melhor ouvir, sentir e compreender historicamente o amplo repertório dos bambas em tempos da ditadura varguista.

\section{Referências}

BOURDIEU, Pierre. O poder simbólico. 5.ed. Rio de Janeiro: Bertrand Brasil, 2002.

CABRAL, Sérgio. No tempo de Almirante: uma história do rádio e da MPB. Rio de Janeiro: Francisco Alves, 1990.

FOUCAULT, Michel. Vigiar e punir: história da violência nas prisões. Petropólis: Vozes, 1977. Microfísica do poder. Rio de Janeiro: Graal, 1979.

GOMES, Angela Maria de Castro. A construção do homem novo: o trabalhador brasileiro. In: OLIVEIRA, Lúcia Lippi; VELOSO, Mônica Pimenta; GOMES, Angela de Castro. Estado novo: ideologia e poder. Rio de Janeiro: Zahar, 1982.

LAGO, Mário. Na rolança do tempo. 3.ed. Rio de Janeiro: Civilização Brasileira, 1977.

PEDRO, Antonio (Tota). Samba da legalidade. Dissertação (Mestrado em História) - USP, São Paulo, 1980.

THOMPSON, E. P. Costumes em comum: estudos sobre a cultura popular tradicional. São Paulo: Companhia das Letras, 1998.

VASCONCELLOS. Gilberto; SUZUKI JR., Matinas. A malandragem e a formação da música popular brasileira. In: FAUSTO, Boris (dir.). História geral da civilização brasileira - III - O Brasil republicano (Economia e cultura: 1930-1964). 3.ed. São Paulo: Difel, 1984.

WILLIAMS, Raymond. Cultura. Rio de Janeiro: Paz e Terra. 1992.

Áureo BUSETTO. Professor Doutor. Departamento de História e Programa de PósGraduação em História, UNESP. Av. Dom Antônio, 2100, Parque Universitário, Assis, 19.806-900 SP, Brasil.

Recebido em: 16/05/2017 Aprovado em: 30/08/2017 